\title{
Rapid depletion of dissolved organic sulphur (DOS) in freshwaters
}

\author{
F. L. Brailsford (iD · H. C. Glanville - D. Wang • P. N. Golyshin • \\ P. J. Johnes $\cdot$ C. A. Yates $\cdot$ D. L. Jones
}

Received: 5 August 2019/Accepted: 26 April 2020/Published online: 2 May 2020

(C) The Author(s) 2020

\begin{abstract}
Sulphur (S) is a key macronutrient for all organisms, with similar cellular requirements to that of phosphorus (P). Studies of $\mathrm{S}$ cycling have often focused on the inorganic fraction, however, there is strong evidence to suggest that freshwater microorganisms may also access dissolved organic S (DOS) compounds (e.g. S-containing amino acids). The aim of this study was to compare the relative concentration and depletion rates of organic ${ }^{35} \mathrm{~S}$-labelled amino acids (cysteine, methionine) with inorganic $\mathrm{S}\left(\mathrm{Na}_{2}{ }^{35} \mathrm{SO}_{4}\right)$ in
\end{abstract}

Responsible Editor: Adam Langley.

Electronic supplementary material The online version of this article (https://doi.org/10.1007/s10533-020-00669-4) contains supplementary material, which is available to authorized users.

F. L. Brailsford $(\bowtie) \cdot$ H. C. Glanville · D. Wang ·

P. N. Golyshin · D. L. Jones

Environment Centre Wales, Bangor University, Bangor,

Gwynedd LL57 2UW, UK

e-mail: fran.brailsford@uwa.edu.au

F. L. Brailsford · P. N. Golyshin · D. L. Jones

Centre for Environmental Biotechnology, Bangor

University, Bangor, Gwynedd LL57 2UW, UK

F. L. Brailsford · D. L. Jones

SoilsWest, UWA School of Agriculture and Environment,

The University of Western Australia, Perth,

WA 6009, Australia oligotrophic versus mesotrophic river waters draining from low nutrient input and moderate nutrient input land uses respectively. Our results showed that inorganic $\mathrm{SO}_{4}{ }^{2-}$ was present in the water column at much higher concentrations than free amino acids. In contrast to $\mathrm{SO}_{4}{ }^{2-}$, however, cysteine and methionine were both rapidly depleted from the mesotrophic and oligotrophic waters with a halving time $<1 \mathrm{~h}$. Only a small proportion of the DOS removed from solution was mineralized and excreted as $\mathrm{SO}_{4}{ }^{2-}(<16 \%$ of the total taken up) suggesting that the DOS could be satisfying a demand for carbon (C) and S. In conclusion, even though inorganic $\mathrm{S}$ was abundant in freshwater, it appears that the aquatic communities retained the capacity to take up and assimilate DOS.

\author{
H. C. Glanville \\ School of Geography, Geology and the Environment, \\ Keele University, Staffordshire ST5 5BG, UK \\ P. J. Johnes - C. A. Yates \\ School of Geographical Sciences, University of Bristol, \\ University Road, Bristol BS8 1SS, UK
}


Keywords Dissolved organic matter - DOS processing · Nutrient cycling · Radioisotopes · Sulphate

\section{Introduction}

Carbon $(\mathrm{C})$, nitrogen $(\mathrm{N})$ and phosphorus $(\mathrm{P})$ have long been considered to be the key macronutrients regulating primary productivity in freshwater environments. Although $\mathrm{S}$ is rarely limiting in freshwaters (Dodds and Whiles 2010), recent stoichiometric studies have found that average cellular sulphur (S) requirements are close to that of $\mathrm{P}(\mathrm{C}: \mathrm{N}: \mathrm{P}: \mathrm{S}$ 124:16:1:1.3; Ho et al. 2003; Ksionzek et al. 2016). As the $\mathrm{C}, \mathrm{N}, \mathrm{P}$ and $\mathrm{S}$ cycles are intrinsically linked through dissolved organic matter (DOM), it is therefore important to consider the cycling of dissolved organic sulphur (DOS). Further, through S-containing peptides, DOS may also play a role in the transport and bioavailability of trace metals (Marie et al. 2015; Ksionzek et al. 2016). Despite the lack of studies on DOS, the concentration of dissolved and particulate forms of organic $\mathrm{S}$ has been shown to exceed that present in an inorganic form (i.e. $\mathrm{SO}_{4}{ }^{2}$ ) in some ecosystems (Levine 2016; Ksionzek et al. 2016). Whilst research has been undertaken to characterise DOS in the marine environment, comprehensive studies of the composition of aquatic DOS pools are lacking (Ksionzek et al. 2016). However, some compounds have been frequently identified and are considered to be of importance in overall $\mathrm{S}$ cycling (e.g. S-containing amino acids, dimethylsulfoniopropionate, DMSP) (Ginzburg et al. 1998; Sela-Adler et al. 2016).

Of the S-containing amino acids, only methionine and cysteine are biosynthetically incorporated into proteins and these are expected to represent the main forms of DOS entering unpolluted freshwaters (Brosnan and Brosnan 2006). Relative to other amino acids, they are generally present at low concentrations in the cell (ca. 1.5-3.5\% of the total amino acid pool; Okayasu et al. 1997). However, they are also precursors for many other cellular metabolites, which can be present at high concentrations. For example, S-adenosyl methionine (SAM) is a co-factor involved in the majority of methyl transfer reactions across all organisms, $N$-formyl methionine acts as the translation
Fig. 1 Land cover map of the Conwy catchment with lowland improved grassland sites (1-3) and upland peat bog sites (4-6) indicated. Created with ArcGIS Hydrology toolbox (ESRI 2018. Version 10 Redlands, CA) using LCM2007 data provided by the Centre for Ecology and Hydrology (Emmett et al. 2016). Reproduced Brailsford et al. (2019)

initiator in prokaryotic protein synthesis and S-methylmethionine is a precursor for DMSP (Brosnan and Brosnan 2006; Ferla and Patrick 2014; SelaAdler et al. 2016). The main role of cysteine is the creation of complex protein structures through the formation of disulphide bonds with other cysteine residues while methionine plays a key role in the initiation of protein translation and often forms part of the hydrophobic core of proteins (Brosnan and Brosnan 2006; Ferla and Patrick 2014). Cysteine may also be used to synthesize methionine in prokaryotes, a process that is reversed in eukaryotic cells (Cooper 1983; Ferla and Patrick 2014; Qiao et al. 2018).

Total DOS and particulate organic S (POS) concentrations in freshwater are rarely reported due to challenges in their measurement, however, measurements of total thiol concentrations (R-SH group; 10-160 nM) indicate their potential importance in long-distance $S$ transport (Marie et al. 2015). In contrast, measurements of individual free S-containing amino acids in the water column indicate that they are only present at extremely low concentrations (0.2-5.0 nM; Horňák et al. 2016), despite their presence in cells at much higher concentrations ( $\mathrm{Li}$ et al. 2017). This suggests that they may be rapidly cycled within freshwaters. We have not identified any previous work investigating the depletion of DOS compounds from aquatic environments or how this compares to inorganic sulphate depletion. The aims of this study were therefore to use ${ }^{35} \mathrm{~S}$-labelled isotopic tracers to: (1) quantify rates of DOS depletion in aquatic ecosystems; (2) compare the rates of depletion of DOS compounds (S-containing amino acids) versus inorganic $\mathrm{S}\left(\mathrm{SO}_{4}{ }^{2-}\right)$ in river waters, and (3) identify differences in $\mathrm{S}$ depletion in two contrasting land cover types. 


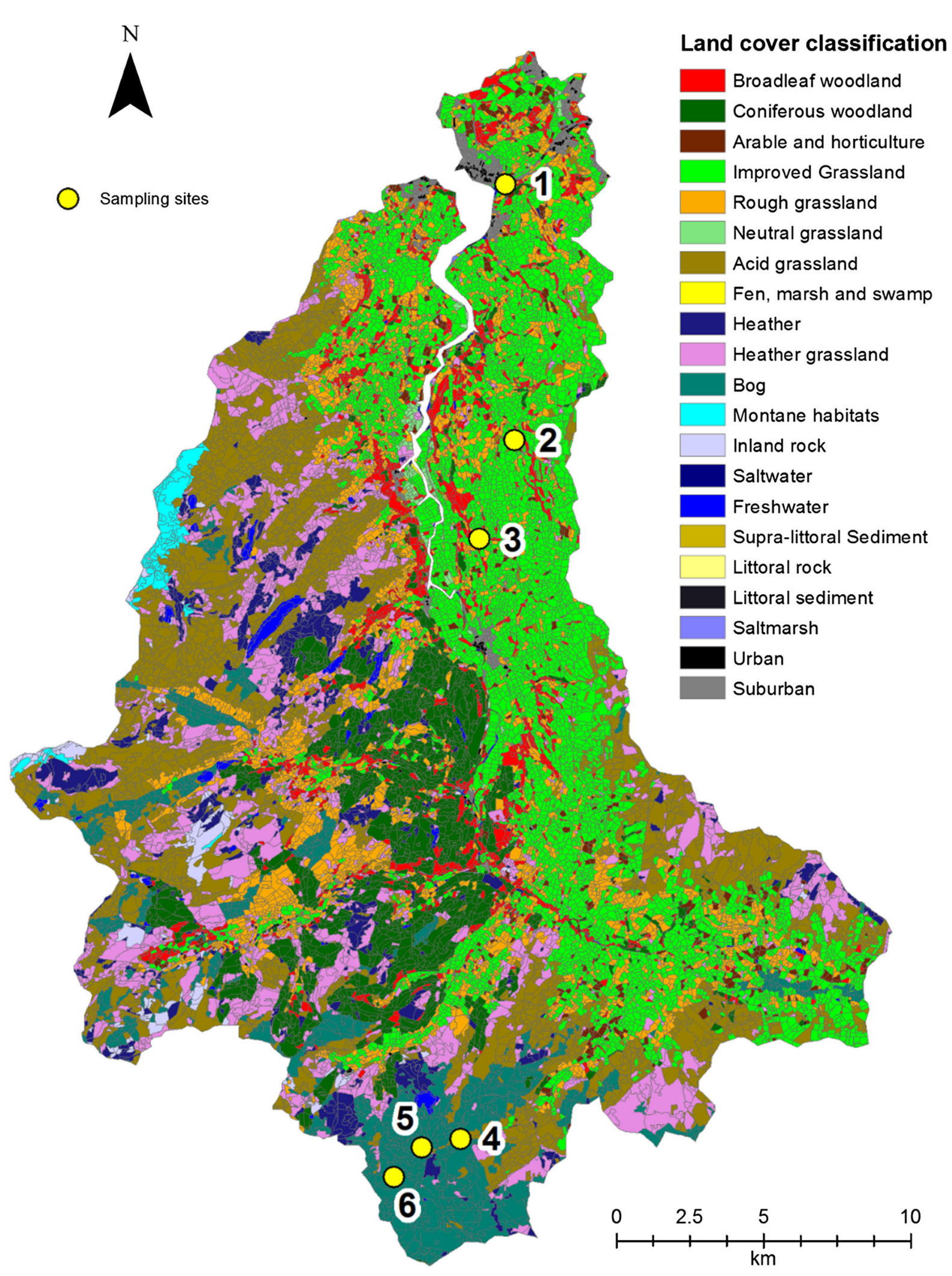




\section{Materials and methods}

Field site

Samples were collected in the spring of 2018, from three independent streams draining each of two contrasting land cover types within the Conwy catchment, Wales, UK (Fig. 1; Emmett et al. 2016). Three replicate $1 \mathrm{~L}$ mid-stream samples were collected manually from $5 \mathrm{~cm}$ below the surface at each site in high-density polyethylene (HDPE) bottles. Samples were kept on ice in the dark during transportation to the laboratory and experiments commenced within 6 $\mathrm{h}$. The first set of samples were collected from mesotrophic streams passing through lowland agricultural grasslands, subject to moderate livestock grazing and fertiliser applications. The second set were collected from three independent oligotrophic headwater streams draining an upland blanket peat bog dominated by acid heathland vegetation, with low intensity sheep grazing and no history of fertiliser application. General water and sediment characteristics of these sites have been previously described (Table 1; Brailsford et al. 2019; Yates et al. 2019).
Chemical characteristics

Thiol concentrations in river water samples were measured using a thiols fluorescent detection kit with an N-acetylcysteine standard (Lot: 18S037A; Invitrogen Inc., Carlsbad, CA). Total reflection X-ray fluorescence (TXRF) elemental analysis of underlying river sediments was measured on dried $\left(40{ }^{\circ} \mathrm{C}\right)$, sieved $(<125 \mu \mathrm{m})$ sediment using a Bruker S2 Picofox TXRF spectrometer (Bruker Inc., MA, USA). The quantification of sulphate was conducted on river water samples by ion chromatography using a 930 Compact IC Flex (Metrohm, Herisau, Switzerland).

${ }^{35}$ S-labelled nutrient depletion assays

Within $6 \mathrm{~h}$ of collection, aliquots of unfiltered river water $(25 \mathrm{~mL})$ were placed in sterile $50 \mathrm{~mL}$ polypropylene centrifuge tubes (Corning Inc., Corning, NY). Each sample was spiked with $200 \mu \mathrm{L}$ of e-pure water (18 M $\Omega$ resistance) containing ${ }^{35} \mathrm{~S}$ labelled methionine, cysteine or sodium sulphate $\left(\mathrm{Na}_{2}{ }^{35} \mathrm{SO}_{4}\right)$ to give a final activity $0.2 \mathrm{kBq} \mathrm{mL}-1$. Compounds were chosen to reflect possible organic (methionine, cysteine) or inorganic $\left(\mathrm{Na}_{2}{ }^{35} \mathrm{SO}_{4}\right) \mathrm{S}$ compounds typically released during the breakdown of particulate organic matter entering soils and

Table 1 Chemical characteristics of the water samples used in the study

\begin{tabular}{|c|c|c|c|c|}
\hline & Lowland mesotrophic & Upland oligotrophic & $\mathrm{F}$ & $P$ value \\
\hline Sulphate (mg S L $\left.{ }^{-1}\right)$ & $0.11 \pm 0.01$ & $0.11 \pm 0.02$ & 0 & 0.877 \\
\hline Total free thiols (ng S L ${ }^{-1}$ ) & $12.7 \pm 3.9$ & BLD & - & - \\
\hline $\mathrm{pH}$ & $7.09 \pm 0.08$ & $4.20 \pm 0.16$ & 14 & $<0.001 *$ \\
\hline Electrical conductivity $\left(\mu \mathrm{S} \mathrm{cm}{ }^{-1}\right)$ & $191 \pm 8$ & $49 \pm 5$ & 13 & $<0.001 *$ \\
\hline Temperature $\left({ }^{\circ} \mathrm{C}\right)$ & $7.53 \pm 0.37$ & $9.00 \pm 0.65$ & 3 & 0.421 \\
\hline Dissolved organic $\mathrm{C}\left(\mathrm{mg} \mathrm{C} \mathrm{L}^{-1}\right)$ & $2.86 \pm 0.13$ & $7.60 \pm 0.62$ & 6 & $<0.001 *$ \\
\hline Total free carbohydrates $\left(\mathrm{mg} \mathrm{C} \mathrm{L}^{-1}\right)$ & $0.11 \pm 0.02$ & $0.09 \pm 0.02$ & 1 & 0.450 \\
\hline Total phenols (mg C L $\mathrm{L}^{-1}$ ) & $2.27 \pm 0.66$ & $1.78 \pm 0.74$ & 0 & 0.667 \\
\hline Total dissolved $\mathrm{N}\left(\mathrm{mg} \mathrm{N} \mathrm{L}^{-1}\right)$ & $2.13 \pm 0.24$ & $0.38 \pm 0.02$ & 7 & $<0.001 *$ \\
\hline $\mathrm{NH}_{4}^{+}\left(\mathrm{mg} \mathrm{N} \mathrm{L}^{-1}\right)$ & $0.05 \pm 0.01$ & $0.06 \pm 0.01$ & 0 & 0.818 \\
\hline $\mathrm{NO}_{3}^{-}\left(\mathrm{mg} \mathrm{N} \mathrm{L}^{-1}\right)$ & $1.73 \pm 0.24$ & $0.02 \pm 0.00$ & 7 & $<0.001 *$ \\
\hline Total free amino acids $\left(\mathrm{mg} \mathrm{N} \mathrm{L}^{-1}\right)$ & $0.10 \pm 0.01$ & $0.13 \pm 0.01$ & 2 & 0.142 \\
\hline Molybdate-reactive $\mathrm{P}\left(\mathrm{mg} \mathrm{P} \mathrm{L}^{-1}\right)$ & $0.07 \pm 0.01$ & $0.03 \pm 0.00$ & 4 & $<0.001 *$ \\
\hline
\end{tabular}

Values represent means \pm SEM, rows $1-3$ are $n=3$, rows 4-11 are $n=9$. *Denotes a significant $P$ value when comparing the two sites. The significance level was set at $P<.05$. Rows $4-11$ reproduced Brailsford et al. (2019). BLD indicates below the limit of detection $\left(<1 \mathrm{ng} \mathrm{S} \mathrm{L}^{-1}\right)$ 
freshwaters. We assumed that the amount of ${ }^{35} \mathrm{~S}$ isotope added to the water $(<0.1 \mathrm{nM})$ did not change the intrinsic concentration of the pool being measured. Sterile controls run with e-pure water in place of river water resulted in no loss of ${ }^{35} \mathrm{~S}$-compounds from solution (Supplementary Fig. S1).

After sealing with sterile caps, the samples were subsequently incubated on a shaker (200 rev $\min ^{-1}$ ) in the dark at $10{ }^{\circ} \mathrm{C}$ for the duration of the experiment. This temperature represents the mean annual temperature within the Conwy catchment (Brailsford et al. 2019). A headspace of at least $25 \mathrm{~mL}$ was maintained throughout the experiment in order to prevent samples from becoming anoxic. After incubation for 1, 2, 4, 6, $24,48,72,144 \mathrm{~h}$, two $1.0 \mathrm{~mL}$ aliquots were removed from the tubes and centrifuged to remove microbial cells $(20,817 \times g, 3 \mathrm{~min}) .0 .5 \mathrm{~mL}$ of the supernatant was either: (1) placed directly into a scintillation vial for ${ }^{35} \mathrm{~S}$ quantification, or (2) added to $0.5 \mathrm{~mL} \mathrm{BaCl}_{2}$ $(0.5 \mathrm{M})$ and centrifuged again $(20,817 \times g, 3 \mathrm{~min})$ to precipitate and remove any inorganic sulphate present in the methionine and cysteine treatments (i.e. $\mathrm{S}$ mineralized from DOS and present in the external media) and the supernatant of the $\mathrm{BaCl}_{2}$ treatment placed into a scintillation vial. The subsamples were then mixed with Optiphase HiSafe 3 scintillation cocktail (4 mL; PerkinElmer Inc., Waltham, MA) and the ${ }^{35} \mathrm{~S}$ quantified on a Wallac 1404 liquid scintillation counter with automated quench correction (Wallac EG\&G, Milton Keynes, UK).
Data analysis

Data analysis was carried out in SPSS v22 (IBM UK Ltd., Portsmouth, UK). DOS values were corrected for any cleaved sulphate groups remaining in solution and analysis of covariance (ANCOVA) was used, with sample time as continuous variable, the ${ }^{35} \mathrm{~S}$ tracer added as a categorical variable and the percentage of ${ }^{35} \mathrm{~S}$ tracer remaining in solution as the dependent variable. One-way ANOVA was used to detect differences between depletion kinetic parameters derived from the curve-fitting, with a significance level set at $P<.05$. Graphs and curve-fitting data were produced using Sigmaplot v13.0 (Systat Software Inc., San Jose, CA). To determine the halving time $\left(t_{1 / 2}\right)$ and decay coefficient $(k)$ of each $S$ compound in river water, single first order exponential decay curves with an asymptote were fitted to the data according to:

$s=y_{0}+\left(a \times \exp ^{-k t}\right)$,

where $s$ is the ${ }^{35} \mathrm{~S}$ remaining in solution, $y_{0}$ represents an asymptote (\%), $k$ is the exponential decay coefficient describing ${ }^{35} \mathrm{~S}$ removal from solution, $a$ is the reactive sulphur pool size (\%) and $t$ is time (h) (Hill et al. 2008). The halving time ( $\left.t_{1 / 2}\right)$ of each $S$ form can then be calculated as:

$t_{1 / 2}=\ln (2) / k$.

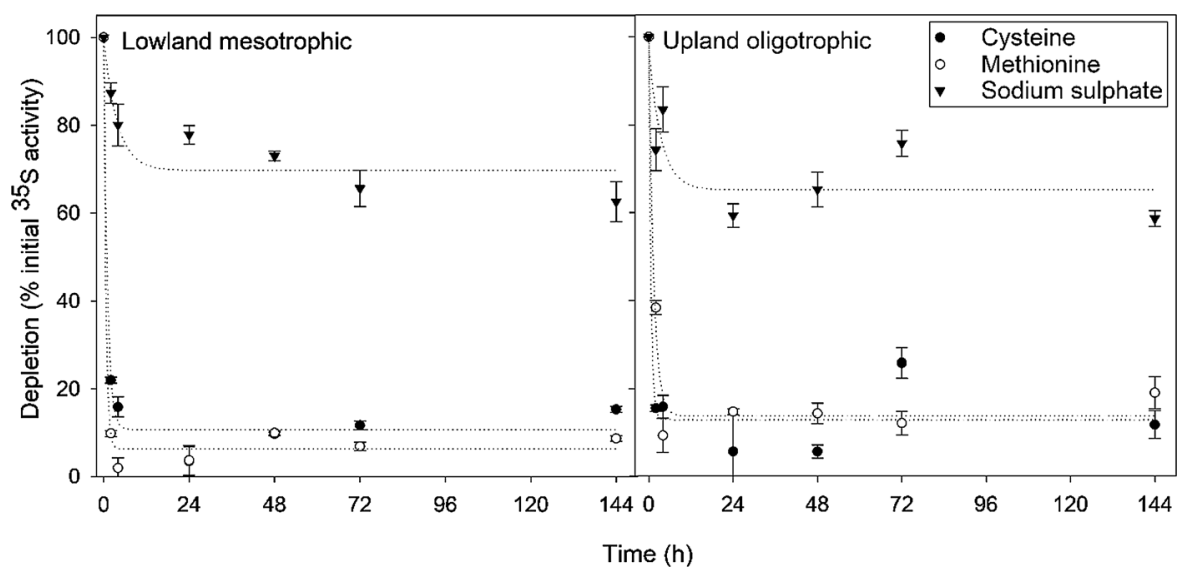

Fig. 2 Depletion of either ${ }^{35} \mathrm{~S}$-labeled DOS compounds (cysteine, methionine) or inorganic sulphur $\left(\mathrm{Na}_{2}{ }^{35} \mathrm{SO}_{4}\right)$ after addition to lowland mesotrophic and upland oligotrophic river water. Values represent means $\pm \operatorname{SEM}(n=3)$ 
Table 2 Model parameters describing the size and turnover of ${ }^{35} \mathrm{~S}$ over time for lowland mesotrophic and upland oligotrophic systems

\begin{tabular}{|c|c|c|c|c|c|c|c|}
\hline & \multicolumn{3}{|c|}{ Lowland mesotrophic } & \multicolumn{3}{|c|}{ Upland oligotrophic } & \multirow[t]{2}{*}{$P$ value } \\
\hline & Cysteine & Methionine & Sodium sulphate & Cysteine & Methionine & Sodium sulphate & \\
\hline$y_{0}$ & $13.7 \pm 1.8^{\mathrm{a}, \mathrm{b}}$ & $8.9 \pm 0.8^{\mathrm{a}}$ & $70.0 \pm 1.5^{\mathrm{d}}$ & $16.6 \pm 0.5 b,^{c}$ & $20.4 \pm 1.6^{\mathrm{c}}$ & $65.2 \pm 1.1^{\mathrm{d}}$ & $<0.001 *$ \\
\hline$a$ & $86.3 \pm 1.9^{\mathrm{c}, \mathrm{d}}$ & $91.1 \pm 0.8^{\mathrm{d}}$ & $28.8 \pm 1.8^{\mathrm{a}}$ & $83.4 \pm 0.5^{\mathrm{b}}$ & $78.9 \pm 1.3^{\mathrm{b}}$ & $30.2 \pm 0.8^{\mathrm{a}}$ & $<0.001 *$ \\
\hline$k$ & $1.11 \pm 0.18^{\mathrm{a}, \mathrm{b}, \mathrm{c}}$ & $2.36 \pm 0.05^{\mathrm{c}}$ & $0.20 \pm 0.03^{\mathrm{a}}$ & $2.06 \pm 0.78^{\mathrm{b}, \mathrm{c}}$ & $0.89 \pm 0.27^{\mathrm{a}, \mathrm{b}}$ & $0.17 \pm 0.06^{\mathrm{a}}$ & $<0.001 *$ \\
\hline$t 1 / 2(\mathrm{~h})$ & $0.64 \pm 0.11^{\mathrm{a}}$ & $0.29 \pm 0.01^{\mathrm{a}}$ & $3.67 \pm 0.65^{\mathrm{a}, \mathrm{b}}$ & $0.39 \pm 0.15^{\mathrm{a}}$ & $0.93 \pm 0.27^{\mathrm{a}}$ & $4.80 \pm 1.32^{\mathrm{b}}$ & $0.003 *$ \\
\hline$r^{2}$ & $0.95 \pm 0.01$ & $0.99 \pm 0.00$ & $0.74 \pm 0.05$ & $0.89 \pm 0.03$ & $0.86 \pm 0.04$ & $0.63 \pm 0.03$ & - \\
\hline
\end{tabular}

The models are described by a single first order exponential decay equation fitted with an asymptote. Values represents means SEM $(n=3)$

\section{Results and discussion}

Sulphur composition in two contrasting land-cover types

In the current study, thiol concentrations were much lower than reported in previous studies, being $0.4 \mathrm{nM}$ for mesotrophic rivers and below the limit of detection $(<0.05 \mathrm{nM})$ for the upland oligotrophic rivers. The former is two orders of magnitude lower than values presented in other studies of freshwaters detected using a static mercury drop electrode (Superville et al. 2013; Marie et al. 2015; Table 1). Sulphate concentrations were similar across the mesotrophic and oligotrophic rivers $(3425 \pm 265$ versus $3415 \pm 583$ nM; one-way ANOVA, $\mathrm{F}_{1,4}=0.161, P=0.709$ ). Although we did not identify individual amino acids, the total concentration of free amino acids was similar between the two river types $(7.38 \pm 0.24$ versus $9.04 \pm 0.95 \mu \mathrm{M})$.

\section{${ }^{35}$ S-labelled depletion}

In the current study, the addition of trace amounts of S-containing amino acids resulted in a rapid depletion from the dissolved fraction for both mesotrophic and oligotrophic waters, whereas $\mathrm{Na}_{2}{ }^{35} \mathrm{SO}_{4}$ was not readily depleted from solution in either treatment (Fig. 2). However, the higher background inorganic S concentrations present in both mesotrophic and oligotrophic waters will have diluted the isotope pool, reducing the depletion of $\mathrm{Na}_{2}{ }^{35} \mathrm{SO}_{4}$ from solution. For both mesotrophic and oligotrophic waters, the compound added had a significant interaction with time, resulting in a difference in depletion over time between S-containing amino acids (cysteine, methionine) and sodium sulphate (ANCOVA, $\mathrm{F}_{1,7}=17, P<.0001$ and $\mathrm{F}_{1,7}=16, P<.0001$ respectively). Overall, very little of the ${ }^{35} \mathrm{~S}$-label present in the amino acid was released into solution as ${ }^{35} \mathrm{SO}_{4}{ }^{2-}(15.2 \pm 3.7 \%$ of the total added), indicating that the majority of the $\mathrm{S}$ remaining in solution had not been completely cleaved from the carbon skeleton. Similarly, a study of S availability to plants in paddy field soils demonstrated higher rates of depletion from ${ }^{35} \mathrm{~S}$ incorporated into the organic components of rice straw compared to $\mathrm{S}$ addition as $\mathrm{Na}_{2}{ }^{35} \mathrm{SO}_{4}$ (Zhou et al. 2006).

In the lowland mesotrophic waters, the rate of methionine depletion from solution appeared higher than that of cysteine, with a reversal of this trend observed in the upland oligotrophic waters. Overall, however, there were no statistically significant differences between the rates of cysteine and methionine depletion from solution, according to the calculated $k$ coefficients (Table 2). The rate of cysteine removal from solution $(k)$ was ca. twice as fast in the upland oligotrophic waters compared to lowland mesotrophic waters, while the reverse was true for methionine (Table 2). The $k$ coefficients determined here for DOS compounds were the same order of magnitude as those previously observed for DON and DOP compounds in rivers and DOC in soil systems (Hill et al. 2008; Islam et al. 2013; Glanville et al. 2016). Similar trends were observed for calculated $t_{1 / 2}$ values; the $t_{1 / 2}$ for methionine was quicker than for cysteine, whereas the reverse was true for upland oligotrophic waters, although not statistically significant (Table 2). This was reflected in 
an increase in $t_{1 / 2}$ for methionine and a decrease in $t_{1 / 2}$ for cysteine from lowland to upland waters. In all treatments, the $t_{1 / 2}$ for the DOS compounds was $<1 \mathrm{~h}$. A rapid initial loss of inorganic $\mathrm{S}\left(\mathrm{Na}_{2}{ }^{35} \mathrm{SO}_{4}\right)$ from solution was observed, with more depletion observed in upland oligotrophic rivers compared to lowland mesotrophic rivers (Table 2). However, depletion did not fall below $50 \%$ in mesotrophic or oligotrophic waters, therefore the calculated $t_{1 / 2}$ values should be treated cautiously (Fig. 2; Table 2). We attribute this lack of $\mathrm{SO}_{4}{ }^{2-}$ depletion to the limitation of the aquatic microbiota by another nutrient, such as carbon, or a lack of available electron acceptors.

It has generally been considered that inorganic $\mathrm{S}$ forms, in addition to cysteine, are the preferred source of $\mathrm{S}$ for the microbial biomass, although fungal species may also use methionine as a preferred source (Kertesz 2000). Previous community analysis of the rivers in the current study found that $<5 \%$ of phospholipid-derived fatty acids (PLFAs) originated from a fungal source, suggesting that the rapid cysteine depletion cannot be ascribed to high proportions of fungal cells within the microbial community (Brailsford et al. 2019). There is literature to support the presence of sulphate starvation induced (SSI) proteins, which are synthesised by a range of cultures of microorganisms when preferred sources of S are not available (Stipanuk 1986; Kertesz et al. 1993; Scott et al. 2007). These enzymes allow other sources of $S$ to be used, altering $\mathrm{S}$ cycling in sulphate-limited conditions, however, the $\mathrm{SO}_{4}{ }^{2-}$ trigger concentration at which their expression occurs in aquatic environments remains unknown.

The current study measured the biotic removal of methionine, cysteine and $\mathrm{Na}_{2}{ }^{35} \mathrm{SO}_{4}$ from freshwaters in isolation at low concentrations. Further studies spanning a broader range of aquatic physicochemical gradients could help to identify the key drivers of changes in DOS depletion from solution (e.g. nutrient concentrations, $\mathrm{pH}$ ). The mesocosm experiment in this study was undertaken in the dark in order to determine the response of heterotrophic organisms to S addition, however autotrophic microorganisms could respond differently to aquatic $S$ inputs. A low percentage of ${ }^{35} \mathrm{~S}$-labelled DOS added was re-released as cleaved ${ }^{35} \mathrm{SO}_{4}{ }^{2-}$, suggesting in the current study DOS was not being taken up by the aquatic microbiota to meet $\mathrm{C} / \mathrm{N}$ requirements alone. In future studies, we suggest using
${ }^{14} \mathrm{C}$ - and ${ }^{15} \mathrm{~N}$-labelled DOS alongside ${ }^{35} \mathrm{~S}$ compounds to provide further insights into the fate of the $\mathrm{C}$ skeleton of DOS compounds. In addition, using a broader range of tracer concentrations would allow the determination of the maximal depletion capacities and nutrient spiralling rates of DOS compounds in aquatic ecosystems, in order to advance our understanding of the capacity for depletion of S-containing amino acids by aquatic microbiota. A previous study of amino acid metabolism of Streptococcus thermophilus in batch fermentations, combining metabolomic and transcriptomic approaches, observed increases in enzymes associated with both cysteine and methionine depletion, despite both amino acids being added to the nutrient broth. This suggests that the rate of depletion from solution may not meet microbial demand for S-containing amino acids (Lahtvee et al. 2011; Qiao et al. 2018). The combination of radiolabelled tracers in conjunction with omics approaches could provide additional insights of the pathways involved in $S$ depletion and metabolism.

\section{Conclusions}

In summary, the results of this study go against the consensus that sulphate is the preferred source of $\mathrm{S}$ for most microorganisms (Kertesz 2000). We found that the S-containing amino acids cysteine and methionine were rapidly removed from solution, whereas inorganic sulphur $\left(\mathrm{Na}_{2}{ }^{35} \mathrm{SO}_{4}\right)$ depletion was limited. Halving times for the compounds in solution were $<1 \mathrm{~h}$ in both mesotrophic and oligotrophic rivers. Limited abiotic depletion of ${ }^{35} \mathrm{~S}$ tracers was observed, therefore we hypothesise that this removal from solution is due to uptake by the aquatic microbiota, as it is more energetically efficient to take up free amino acids and directly incorporate them in proteins in comparison to the uptake of $\mathrm{SO}_{4}{ }^{2-}$ and de novo amino acid biosynthesis. This is especially the case for S-containing amino acids which are energetically costly to produce in comparison to other amino acids (Akashi and Gojobori 2002). As the DOS compounds studied here represent a tri-nutrient source $(\mathrm{C}, \mathrm{N}$ and $\mathrm{S})$ these low molecular weight forms of $\mathrm{S}$ also negate the need to take up as much inorganic N. Further work is required to a wider range of DOS compounds and also to quantify their rates of production. This will 
enable a quantitative assessment of the overall role of DOS in freshwater $\mathrm{S}$ cycling.

Acknowledgements This work was carried out under the DOMAINE Project (NERC Large Grant NE/K010689/1). FB, DLJ and PNG would like to acknowledge the support of the Centre of Environmental Biotechnology Project, part-funded by the European Regional Development Fund (ERDF) through the Welsh Government. Thanks to Inma Lebron Robinson for help with IC anion analysis.

Open Access This article is licensed under a Creative Commons Attribution 4.0 International License, which permits use, sharing, adaptation, distribution and reproduction in any medium or format, as long as you give appropriate credit to the original author(s) and the source, provide a link to the Creative Commons licence, and indicate if changes were made. The images or other third party material in this article are included in the article's Creative Commons licence, unless indicated otherwise in a credit line to the material. If material is not included in the article's Creative Commons licence and your intended use is not permitted by statutory regulation or exceeds the permitted use, you will need to obtain permission directly from the copyright holder. To view a copy of this licence, visit http://creativecommons.org/licenses/by/4.0/.

\section{References}

Akashi H, Gojobori T (2002) Metabolic efficiency and amino acid composition in the proteomes of Escherichia coli and Bacillus subtilis. Proc Natl Acad Sci USA 99:3695-3700

Brailsford FL, Glanville HC, Golyshin PN, Johnes PJ, Yates CA, Jones DL (2019) Microbial uptake kinetics of dissolved organic carbon (DOC) compound groups from river water and sediments. Sci Rep 9:11229

Brosnan JT, Brosnan ME (2006) The sulphur-containing amino acids: an overview. J Nutr 136:1636S-1630S

Cooper AJL (1983) Biochemistry of sulfur-containing amino acids. Annu Rev Biochem 52:187-222

Dodds WK, Whiles MR (2010) Freshwater ecology: concepts and environmental applications in limnology. Academic Press, London

Emmett BA, Cooper D, Smart S et al (2016) Spatial patterns and environmental constraints on ecosystem services at a catchment scale. Sci Tot Environ 572:1586-1600

Ferla MP, Patrick WM (2014) Bacterial methionine biosynthesis. Microbiology 160:1571-1584

Ginzburg B, Chalifa I, Gun J, Dor I, Hadas O, Lev O (1998) DMS formation by dimethylsulfoniopropionate rute in freshwater. Environ Sci Technol 32:2130-2136

Glanville HC, Hill PW, Schnepf A, Oburder E, Jones DL (2016) Combined use of empirical data and mathematical modelling to better estimate the microbial turnover of isotopically labelled carbon substrates in soil. Soil Biol Biochem 94:154-168
Hill PW, Farrar JF, Jones DL (2008) Decoupling of microbial glucose uptake and mineralization in soil. Soil Biol Biochem 40:616-624

Ho T-Y, Quigg A, Finkel ZV, Milligan AJ, Wyman K, Falkowski PG, Morel FMM (2003) The elemental composition of some marine phytoplankton. J Phycol 39:1145-1150

Horňák K, Schmidheiny H, Pernthaler J (2016) High-throughput determination of dissolved free amino acids in unconcentrated freshwater by ion-pairing liquid chromatography and mass spectrometry. J Chromatogr A 1440:85-93

Islam MJ, Jang C, Eum J, Jung S-M, Shin M-S, Lee Y, Choi Y, Shin C, Kim B (2013) The decomposition rates of organic phosphorus and organic nitrogen in river waters. J Freshw Ecol 28:239-250

Kertesz MA (2000) Riding the sulfur cycle-metabolism of sulfonates and sulfate esters in Gram-negative bacteria. FEMS Microb Rev 24:135-175

Kertesz MA, Leisinger T, Cook AM (1993) Proteins induced by sulfate limitation in Escherichia coli, Pseudomonas putida, or Staphylococcus aureus. J Bacteriol 175:1187-1190

Ksionzek KB, Lechtenfeld OJ, McCallister SL, Schmitt-Koplin P, Geuer JK, Geibert W, Koch BP (2016) Dissolved organic sulfur in the ocean: biogeochemistry of a petagram inventory. Science 354:456-459

Lahtvee P-J, Adamberg K, Arike L, Nahku R, Aller K, Vilu R (2011) Multi-omics approach to study the growth efficiency and amino acid metabolism in Lactococcus lactis at various specific growth rates. Microb Cell Fact 10:12

Levine NM (2016) Putting the spotlight on organic sulfur. Science 354:418-419

Li S-S, Guan Q-Y, Zheng M, Wang Y-Q, Ye D, Kang B, Xu J-J, Chen H-Y (2017) Simultaneous quantification of multiple endogenous biothiols in single living cells by plasmonic Raman probes. Chem Sci 8:7582-7587

Marie L, Pernet-Coudrier B, Waeles M, Gabon M, Riso R (2015) Dynamics and sources of reduced sulfur, humic substances and dissolved organic carbon in a temperate river system affected by agricultural practices. Sci Total Environ 537:23-32

Okayasu T, Ikeda M, Akimoto K, Sorimachi K (1997) The amino acid composition of mammalian and bacterial cells. Amino Acids 13:379-391

Qiao Y, Liu G, Leng C, Zhang Y, Lv X, Chen H, Sun J, Feng Z (2018) Metabolic profiles of cysteine, methionine, glutamate, glutamine, arginine, aspartate, asparagine, alanine and glutathione in Streptococcus thermophilus during $\mathrm{pH}$ controlled batch fermentations. Sci Rep 8:12441

Scott C, Hilton ME, Coppin CW, Russell RJ, Oakeshott JG, Sutherland TD (2007) A global response to sulfur starvation in Pseudomonas putida and its relationship to the expression of low-sulfur-content proteins. FEMS Microbiol Lett 267:184-193

Sela-Adler M, Said-Ahmad W, Sivan O, Eckert W, Kiene RP, Amrani A (2016) Isotopic evidence for the origin of dimethylsulfide and dimethylsulfoniopropionate-like compounds in a warm, monomictic freshwater lake. Environ Chem 13:340-351

Stipanuk MH (1986) Metabolism of sulfur-containing amino acids. Annu Rev Nutr 6:179-209 
Superville PJ, Pižeta I, Omanović D, Billon G (2013) Identification and on-line monitoring of reduced sulphur species (RSS) by voltammetry in oxic waters. Talanta 112:55-62

Yates CA, Johnes PJ, Owen AT, Brailsford FL, Glanville HC, Evans CD, Marshall MR, Jones DL, Lloyd CEM, Jickells T, Evershed RP (2019) Variation in dissolved organic matter (DOM) stoichiometry in U.K. freshwaters: assessing the influence of land cover and soil C:N ratio on DOM composition. Limnol Oceanogr 9999:1-13
Zhou W, Li S, He P, Lin B (2006) Transformation of sulfate and organic $S$ in rice straw in flooded paddy soils and its availability to plants using sulfur-35 labeling. Geoderma 132:1-8

Publisher's Note Springer Nature remains neutral with regard to jurisdictional claims in published maps and institutional affiliations. 